\title{
Hubungan Kadar Profil Lipid dengan Kejadian Hipertensi pada Masyarakat Etnik Minangkabau di Kota Padang Tahun 2012
}

\author{
Rahmat Feryadi, Delmi Sulastri, Husnil Kadri
}

\begin{abstract}
Abstrak
Hipertensi merupakan masalah kesehatan yang banyak dijumpai pada masyarakat dan berkorelasi dengan penyakit lainnya. Banyak faktor penyebab terjadinya hipertensi, salah satunya adalah gangguan profil lipid. Profil lipid dapat memicu terjadinya hipertensi melalui berbagai mekanisme, baik secara langsung atau tidak langsung. Penelitian ini bertujuan untuk meneliti lebih lanjut tentang hubungan obesitas dengan kejadian hipertensi. Penelitian dilakukan pada masyarakat Etnik Minangkabau di 8 kelurahan di kota Padang. Ini adalah studi komparatif menggunakan desain cross sectional study, dengan jumlah subjek 160 responden. Pengumpulan data responden dilakukan dengan wawancara. Pengukuran tekanan darah dilakukan berdasarkan cara yang direkomendasikan WHO dan penetapan nilainya berdasarkan JNC VII. Profil lipid diukur dilaboratorium dengan acuan penilaian berdasarkan NCEP ATP III. Analisis statistik yang digunakan adalah uji chi square. Hasil penelitian ini menunjukkan bahwa sebagian besar gangguan kadar kolesterol terdapat pada penderita hipertensi dari pada normotensi. Uji statistik chi square menunjukkan hubungan yang bermakna antara kadar kolesterol dan trigliserida dengan kejadian hipertensi (total kolesterol $p<0,05 ; \mathrm{OR}=2,40$, trigliserida $\mathrm{p}<0,05$; OR $=2,49$ ). Kadar HDL dan LDL tidak menunjukkan hubungan yang bermakna terhadap kejadian hipertensi $(p>0,05)$. Dari hasil tersebut dapat disimpulkan bahwa sebagian fraksi profil lipid mempengaruhi kejadian hipertensi pada etnik Minangkabau yang berada di kota Padang, yaitu kadar kolesterol total dan trigliserida.
\end{abstract}

Kata kunci: Hipertensi, kolestertol total, HDL, LDL, Trigliserida, etnik Minangkabau.

\begin{abstract}
Hypertension is a common disease in the community and have correlation with other diseases. Many factor can leads hypertension, such as disturbance of lipid profile. Lipid profile can lead hypertension through a variety of mechanism, either directly or indirectly. This study aims to investigate the lipid profile relation with the incident of hypertension. The research was conducted at the Minangkabau ethnic communities in 8 district in Padang city. This was s a comparative study using a cross sectional study in 160 respondents. Data was collected by interview to get respondent characteristics. Measurement of blood preasure waist and carried out by the WHO recommended and appointment value based on JNC VII. Profile lipid was measured in laboratory and appointment value based on NCEP ATP III. The statistical analysis used chi square test. The result found that the disturbance of total cholesterol and trigliceride more existed in hypertension than normotension population. Chi square statistical test showed there was relation between total cholesterol and triglycerides with hypertension incident (total cholesterol $p<0,05 ; O R=2,40$, triglycerides $p<0,05 ; O R=2,49)$. HDL and $L D L$ had not significant relation with hypertension incident $(p>0.05)$. The conclusion of this study is some of profil lipid effected hypertension incident at Minangkabau Ethnic in Padang, especially total cholesterol and triglycerides.
\end{abstract}

Keywords: Hypertension, total cholesterol, HDL, LDL, triglycerides, Minangkabau Ethnic

Affiliasi penulis : Fakultas Kedokteran Universitas Andalas Korespondensi : Rahmad Feryadi, email :

husnilbiokimia@yahoo.com, Telp: 0751-31746

\section{PENDAHULUAN}

Salah satu yang menjadi masalah kesehatan dunia saat ini adalah hipertensi. Hipertensi merupakan penyakit tidak menular yang berasosiasi dengan penyakit tidak menular lainnya seperti penyakit jantung koroner, stroke dan penyakit ginjal yang disebabkan oleh hipertensi yang tidak dikendalikan secara baik.Hipertensi menyebabkan 1 dari 8 kematian yang ada diseluruh dunia. Berdasarkan data WHO tahun 2000, hipertensi telah menjangkiti $26,4 \%$ populasi dunia, dimana sepertiga dari populasi hipertensi berada di negara berkembang dan duapertiga berada di negara maju. Hal ini terlihat pada laporan National
Health and Nutrition Examination Survei (NHANES) tahun 1999-2000 insiden hipertensi orang dewasa mencapai $29-31 \%$ setara dengan $58-65$ juta orang di Amerika ${ }^{1-3}$

Di Indonesia persentase penderita hipertensi berkisar 5-10\% dari jumlah penduduk Indonesi.Hasil Survei Kesehatan Rumah Tangga (SKRT) tahun 2004 menunjukkan jumlah penderitahipertensi berkisar $13,4 \%$ hingga $14,6 \%$ atau rata-rata $14 \%$. Untuk ratio jenis kelamin penderita hipertensi laki-laki 12,2\% sementara perempuan sebesar 15,5\%. Tahun 2007 rata-rata penderita hipertensi pada semua provinsi di Indonesia adalah 32,2\%, termasuk kasus yang sedang dalam kondisi minum obat. Dengan jumlah penderita hipertensi terbanyak pada provinsi Kalimantan Selatan $(39,6 \%)$.Sementara jumlah penderita hipertensi terendah terdapat pada provinsi Papua Barat $(20,1 \%)$. 
Sementara pada kasus tanpa minum obat terdapat rata-rata sebesar 28,3\%. Prevalensi tertinggi tetap berada di Kalimantan Selatan (35,0\%) dan yang terendah juga tetap pada Papua Barat $(17,6 \%){ }^{1,5}$

Pada stadium awal sering tanpa disertai dengan keluhan, tetapi lambat laun akan berpengaruh pada organ penting tubuh. Yang paling sering dikenai adalah ginjal (kegagalan fungsi ginjal), otak (stroke), jantung (penyakit jantung hipertensi hingga penyakit jantung koroner), paru dan hepar.Pada penelitian yang dilakukan oleh Jusman Djafar dan Nasrul Idris di bagian Penyakit Dalam RSUP. M. Djamil Padang, ditemukan angka mortalitasnya sekitar 52,49\%, Secara umum di daerah Sumatera Barat terdapat $31,2 \%$ penderita hipertensi disertai dengan penderita yang sedang dalam kondisi minum obat, dan $26,4 \%$ jika tanpa disertai penderita hipertensi yang sedang dalam kondisi minum obat hipertensi. ${ }^{6,7}$

Pada prakteknya hipertensi merupakan masalah yang sering juga dihadapi langsung oleh petugas layanan kesehatan primer (dokter umum/keluarga). Salah satu kasus berdasarkan klasifikasi WHO yang cukup sering dihadapi adalah perkembangan "hipertensi borderline" (140-159/9094) yang selama 2 tahun $20,4 \%$ menjadi tensi normal, $46,9 \%$ tetap tensi boderline, 32,7\% menjadi hipertensi. Hipertensi merupakan penyakit dengan multifaktor. Secara umum penyebab kejadian hiperetnsi adalah umur, jenis kelamin, perilaku dan aktifitas fisik tingginya kadar kolesterol darah dan diabetes melitus.Selain itu menurut Patel faktor risiko hipertensi yang lain adalah ras, riwayat hipertensi dalam keluarga konsumsi alkohol dan riwayat merokok, lemak, gula danobesitas. Lipid juga merupakan masalah yang penting dalam mempengaruhi kejadian hipertensi, ini berdasarkan kesimpulan yang di sampaikan oleh Patel dan beberapa penelitian lainnya. ${ }^{8}$

Pada peningkatan kadar profil lipid darah sangat erat hubungannya dengan aterosklerosis, terutama pada usia 30-40 tahun, kadar kolesterol total dalam darah mencapai $260 \mathrm{mg} / \mathrm{dl}$ maka angka kejadian aterosklerosis akan meningkat 3-5 kali lipat. Selain itu penelitian epidemiologi, laboratorium dan klinik yang dilakukan Framing Heart Study (FH) dan Multiple Risk Faktor Intervention Trial (MRFIT), membuktikan bahwa gangguan metabolism lipid merupakan faktor sentral terjadinya atreosklerosis. Berdasarkan sebaran geografisnya juga dapat mempengaruhi sebaran hipertensi. Masyarakat yang berada di daerah tepi pantai akan lebih tinggi prevalensinya dibandingkan yang berada di daerah jauh dari pantai atau tak dikelilingi laut. Sebagai contoh, daerah Bangka Belitung memiliki jumlah penderita hipertensi yang lebih tinggi di bandingkan dengan daerah Jawa terutama yang berada jauh dari pantai. ${ }^{8-11}$

Sesuai dengan data yang telah di ungkapkan, hipertensi merupakan gangguan yang mendapatkan perhatian serius, selain komplikasi pada organ target dan cenderung tidak menimbulkan gejala yang berarti pada awal terkenanya sehingga disebut "silent disease". Jumlah penderita gangguan kardiovaskular ini cenderung tinggi di Sumatera Barat di bandingkan provinsi lainnya di Indonesia yang banyak didiami oleh masyarakat Etnik Minangkabau, hal ini disebabkan oleh pola konsumsi yang ada pada masyarakat tersebut. Peningkatan penderita hipertensi di Sumatera Barat cenderung meningkat. Kurun waktu
1977 hingga 2005 terjadi peningkatan penderita hipertensi sebesar $20 \%$. ${ }^{1,12}$

Di Kota Padang sebagai ibukota Provinsi Sumatera Barat, prevalensi gangguan kardiovaskular juga cenderung tinggi, terutama pada usia dewasa hingga usia lanjut.Gangguan tersebut sebagian besar berkaitan dengan kadar lipid dalam darah. Dalam penelitian Kamso menemukan gangguan pada profil lipid, yang didominasi oleh peninggian kadar kolesterol total (>240 mg/dl sebesar 56,1\%), LDL (>160 mg/dl sebesar 64,6\%). Sementara trigliserida memiliki angka signifikan dibawah keduanya (>200 mg/dl sebesar $6,1 \%)$ dan kadar HDL yang rendah $(<3,5 \mathrm{mg} / \mathrm{dl}$ sebanyak $3,7 \%)^{13}$

Usia yang terus bertambah juga akan mempengaruhi jumlah hipertensi secara epidemiologi. Jumlah penderita hipertensi ini diperkirakan meningkat di masa yang akan datang sehingga meningkatkan angka morbiditas akibat gangguan pada organ target dan mortalitas, sehingga perlu dilakukan penelitian lebih dalam pada populasi masyarakat atas faktor risiko yang sudah ada, dan salah satu yang cukup berpengaruh adalah kadar profil lipid. ${ }^{13}$

Berdasarkan penelitan yang dilakukan sebelumnya mengenai profil lipid dan kejadian hipertensi yang cenderung tinggi di Sumatera Barat, maka dilakukan penelitian apakah terdapat hubungan anatara kadar profil lipid dengan kejadian pada etnik Minangkabau yang merupakan mayoritas suku di daerah Sumatera Barat, dan Kota Padang sebagai ibukota provinsinya. Profil lipid yang di teliti adalah kolesterol total, trigliserida, HDL, danLDL.

\section{METODE}

Jenis penelitian ini menggunakan study comparative dengan desain cross sectional study.Populasi penelitian ini adalah masyarakat Etnik Minangkabau yangberusia 35-65 tahun yang berada di kota Padang. Sampel penelitian ini adalah masyarakat Etnik Minangkabau dengan usia yang sesuai pada Kecamatan Padang Selatan, Kecamatan Padang Timur, Kecamatan Kuranji dan Kecamatan Koto Tangah.Berdasarkan rumus yang digunakan di dapatkan jumlah sampelminimal adalah 80 orang termasuk drop out sebanyak 7 orang, nantinya akan di bedakan 80 orang kelompok hipertensi dan 80 orang kelompok normotensi. Pengambilan sampel dilakukan dengan multy stage random sampling.Setelah di dapatkan secara acak 4 kecamatan di Kota Padang, akan diacak kembali kelurahan pada masing-masing kecamatan. Satu kecamatan akan diambil 2 kelurahan sehingga didapatkan 8 kelurahan sampel. Setelah di seleksi berdasarkan kriteria inklusi dan eklusi didapatkan jumlah responden sebanyak 80 orang. Kriteria inklusi penelitian adalah usia 35-65 tahun, Etnik Minangkabau, bertempat tinggal pada kelurahan tempat penelitian, berpuasa selama 10 jam sebelum dilakukan pengambilan darah, bersedia untuk melakukan pemeriksaan dengan penandatanganan informed concent. Sementara kriteria eklusi penelitian ini adalah respondentidak hadir, hipertensi dengan penyakit lain, sedang dalam pengaruh obat anti hipertensi dan kolesterol. Data karakteristik responden didapatkan dengan kuisioner dan pemeriksaan langsung. Dari data kuisioner didapatkan usia dan jenis kelamin responden. Pada pemeriksaan langsung dilakukan pengukuran tekanan darah, dan pengambilan darah untuk mengukur kadar profil lipid. 
Pengukuran tekanan darah dilakukan dengan pedoman yang direkomendasikan oleh WHO. Pedoman klasifikasi hipertensi yang digunakan adalah JNC VII tahun 2003.Pengukuran tekanan darah dilakukan oleh 2 orang doter dari Fakultas Kedokteran Universitas Andalas. Sementara penilaian kadar profil lipid darah dilakukan di Laboratorium RSUP. M. Djamil Padang. Pengambilan sampel darah dilakukan oleh 1 dokter dibantu oleh 1 orang mahasiswa dari Fakultas Kedokteran Universitas Andalas. Pedoman klasifikasi di lakukan berdasarkan NCEP ATP III yang telah di modifikasi. Pengukuran dilakukan untuk menentukan kadar Kolesterol total, HDL, LDL dan trigliserida dalam darah.

Pada pengukuran tekanan darah dilakukan dengan sphygmomanometer air raksa.Sebelum pengukuran reponden di istirahatkan minimal 5 menit. Pengukuran tekanan darah dilakukan sebanyak 2 kali dalam posis duduk dan posisikan lengan agar arteri brakialis dalam posisi setinggi jantung.

Pengolahan data dilakukan dengan metode editing untuk memeriksa kelengkapan dan kejelasan data .Coding pemeberian kode pada masing-masing sampel yang didapatkan. Entry, memasukkan data ke dalam Statistic Program for Social Science (SPSS). Cleaning, pemeriksaan kembali untuk memastikan bahwa data yang didapatkan telah bersih dari kesalahan.

Analisis data yang digunakan adalah analisis univariat dan analisis multifariat.Analisis bivariat digunakan dengan uji statistik chi-square dengan batas kemaknaan $p<0,05$. Tujuannya untuk menentuukan hubungan antara variabel dependen tekanan darah dan variabel independen profil lipid.Kemudian dilihat juga nilai OR (Odd Ratio) untuk melihat estimasi untuk terjadinya out come dengan adanya hubungan antara variabel dependen dan independen.

HASIL

Responden pada penelitin ini adalah masyarakat Etnik Minangkabau usia 35-65 tahun yang ada pada 8 kelurahan di Kota Padang. Terbagi atas 3 kelompok umur, > 45 tahun, 45-54 tahun, dan >54 tahun.jumlah responden terbanyak adalah pasda kelompok usia>54 tahun pada responden hipertensi, dan <45 tahun untuk kelompok normotensi. Sementara berdasarkan jenis kelmain, kelompok hipertensi lebih banyak responden perempuan, dan reponden normotensi banyak didominasi kelompok laki-laki. Pada kelompok hipertensi rerata tekanan darah sistoliknya adalah $162,11 \mathrm{mmHg}$, nilai makasimalnya $220 \mathrm{mmHg}$ dan minimalnya $120 \mathrm{mmHg}$ dengan $S D \pm 17,08$ dan rerata tekanan darah diastoliknya adalah $93,28 \mathrm{mmHg}$ nilai maksimalnya $120 \mathrm{mmHg}$, nilai minimal $50 \mathrm{mmHg}$ dengan SD $\pm 8,61$. Sementara pada kelompok normotensi rerata tekanan darah sistoliknya adalah 119,67 , nilai maksimalnya $140 \mathrm{mmHg}$, nilai minimalnya $100 \mathrm{mmHg}$ dengan $\mathrm{SD} \pm 10,45$ dan rerata tekanan darah diastoliknya adalah $76,71 \mathrm{mmHg}$, nilai maksimalnya adalah 90 $\mathrm{mmHg}$, nilai minimalnya $50 \mathrm{mmHg}$ dan $\mathrm{SD} \pm 7,10$.

\section{Gambaran Kadar Kolesterol Total}

Rerata kadar kolesterol total responden hipertensi $243,27 \mathrm{mg} / \mathrm{dl}$ dengan nilai maksimal 388 $\mathrm{mg} / \mathrm{dl}$ dan nilai minimal $82 \mathrm{mg} / \mathrm{dl}, \mathrm{SD} \pm 49,79$. Rerata kadar kolesterol total responden normotensi 225,41 $\mathrm{mg} / \mathrm{dl}$ dengan nilai maksimal $344 \mathrm{mg} / \mathrm{dl}$ dan nilai minimal $154 \mathrm{mg} / \mathrm{dl}$. SD \pm 154 . Nilai $p$ adalah 0,02 .

\section{Gambaran Kadar HDL}

Rerata kadar HDL responden hipertensi $53,91 \mathrm{mg} / \mathrm{dl}$ dengan nilai maksimal $85 \mathrm{mg} / \mathrm{dl}$, nilai minimal $33 \mathrm{mg} / \mathrm{dl}, \mathrm{SD} \pm 11,90$. Rerata kadar HDL responden normotensi 49,22 $\mathrm{mg} / \mathrm{dl}$ dengan nilai maksimal $65 \mathrm{mg} / \mathrm{dl}$ dan nilai minimal $37 \mathrm{mg} / \mathrm{dl}$, $\mathrm{SD} \pm 7,45$. Nilai $p$ adalah 0,003 .

\section{Gambaran Kadar Trigliserida}

Rerata kadar trigliserida responden hipertensi 167,92 $\mathrm{mg} / \mathrm{dl}$ dengan nilai maksimal $354 \mathrm{mg} / \mathrm{dl}$ dan nilai minimal $77 \mathrm{mg} / \mathrm{dl}, \mathrm{SD} \pm 71,23$. Rerata kadar trigliserida responden normotensi $142 \mathrm{mg} / \mathrm{dl}$ dengan nilai maksimal $483 \mathrm{mg} / \mathrm{dl}$ dan nilai minimal $60 \mathrm{mg} / \mathrm{dl}$, $\mathrm{SD} \pm 83,66$. Nilai $p$ adalah 0,04 .

\section{Gambaran kadar LDL}

Rerata kadar LDL responsden hipertensi $158,88 \mathrm{mg} / \mathrm{dl}$ dengan nilai maksimal $293 \mathrm{mg} / \mathrm{dl}$ dan nilai minimal $94 \mathrm{mg} / \mathrm{dl} . \mathrm{SD} \pm 41,15$. Rerata kadar LDL responden normotensi 148,01 $\mathrm{mg} / \mathrm{dl}$ dengan nilai maksimal $270 \mathrm{mg} / \mathrm{dl}$ dan nilai minimal $79 \mathrm{mg} / \mathrm{dl}$. $\mathrm{SD} \pm 39,43$. Nilai $p$ adalah 0,09 .

\section{Hubungan kadar profil lipid dengan kejadian hipertensi \\ Hubungan kadar kolesterol total dengan kejadian hipertensi}

Proporsi responden yang mempunyai kadar kolesterol total tidak normal lebih banyak yang mengalami hipertensi dari pada normotensi. Hasil uji statistik chi-square didapatkan terdapat hubungan antara kadar kolesrterol dengan kejadian hipertensi nilai $p=0,04$. Dengan nilai $\mathrm{OR}=2,09$ dan $95 \% \mathrm{Cl}$ $(1,1-3,99)$. Dimana responden yang memiliki kadar kolesterol tidak normal memiliki kolesterol tidak normal beresiko terjadinya hipertensi 2,09 kali lebih banyak dari pada yang memiliki kadar kolesterol normal.

Tabel 1. Hubungan Kadar Kolesterol Total dengan Kejadian Hipertensi

\begin{tabular}{|c|c|c|c|c|c|c|c|c|}
\hline \multirow{3}{*}{ Kadar LDL } & \multicolumn{4}{|c|}{ Kejadian Hipertensi } & \multirow{2}{*}{\multicolumn{2}{|c|}{ Jumlah }} & \multirow{3}{*}{$\mathbf{P}$} & \multirow{3}{*}{$\begin{array}{c}\text { OR } \\
(95 \% \mathrm{Cl}\end{array}$} \\
\hline & \multicolumn{2}{|c|}{ Hipertensi } & \multicolumn{2}{|c|}{ Normotensi } & & & & \\
\hline & $f$ & $\%$ & $f$ & $\%$ & $\mathbf{F}$ & $\%$ & & \\
\hline $\begin{array}{l}\text { Tidak } \\
\text { Normal }\end{array}$ & 39 & 60,9 & 25 & 39,1 & 64 & 100 & & 2,09 \\
\hline Normal & 41 & 42,7 & 55 & 57,3 & 96 & 100 & 0,04 & $1,1-3,99$ \\
\hline Jumlah & 80 & & 80 & & 160 & & & \\
\hline
\end{tabular}

Hubungan Kadar HDL dengan kejadian hipertensi Proporsi responden yang mempunyai kadar HDL tidak normal sama jumlahnya yang mengalami 
hipertensi dan normotensi. Hasil uji statistik chi-square didapatkan tidak terdapat hubungan antara HDL dengan kejadian hipertensi nilai $p=0,73$. Dengan nilai $\mathrm{OR}=0,84$ dan $95 \% \mathrm{Cl}(0,43-2,46)$. Dimana kadar HDL bukan faktor resiko terjadinya hipertensi pada responden.

Tabel 2. Hubungan Kadar HDL dengan Kejadian Hipertensi

\begin{tabular}{|c|c|c|c|c|c|c|c|c|}
\hline \multirow{3}{*}{ Kadar LDL } & \multicolumn{4}{|c|}{ Kejadian Hipertensi } & \multirow{2}{*}{\multicolumn{2}{|c|}{ Jumlah }} & \multirow{3}{*}{$\mathbf{P}$} & \multirow{3}{*}{$\begin{array}{c}\text { OR } \\
(95 \% \mathrm{Cl})\end{array}$} \\
\hline & \multicolumn{2}{|c|}{ Hipertensi } & \multicolumn{2}{|c|}{ Normotensi } & & & & \\
\hline & $f$ & $\%$ & $f$ & $\%$ & $F$ & $\%$ & & \\
\hline $\begin{array}{l}\text { Tidak } \\
\text { Normal }\end{array}$ & 23 & 46,94 & 26 & 53,06 & 49 & 100 & & 0,84 \\
\hline Normal & 57 & 51,35 & 54 & 48,65 & 111 & 100 & 0,73 & $0,43-2,46$ \\
\hline Jumlah & 80 & & 80 & & 160 & & & \\
\hline
\end{tabular}

\section{Hubungan kadar trigliserida dengan kejadian hipertensi}

Proporsi responden yang memiliki kadar trigliserida tidak normal lebih banyak pada mengalami hipertensi dari pada normotensi.Hasil uji statistic chisquare diperoleh nilai $p=0,04$. Dengan nilai $O R=$ 2,49 dan $95 \% \mathrm{Cl}(1,09-5,71)$. Dimana kadar trigliserida tidak normal merupakan faktor resiko terjadinya hipertensi sebesar 2,49 kali dari pada yang memiliki kadar trigliserida normal.

Tabel 3. Hubungan Kadar Trigliserida dengan

\begin{tabular}{|c|c|c|c|c|c|c|c|c|}
\hline \multirow{3}{*}{ Kadar LDL } & \multicolumn{4}{|c|}{ Kejadian Hipertensi } & \multirow{2}{*}{\multicolumn{2}{|c|}{ Jumlah }} & \multirow{3}{*}{$\mathbf{P}$} & \multirow{3}{*}{$\begin{array}{c}\text { OR } \\
(95 \% \mathrm{Cl})\end{array}$} \\
\hline & \multicolumn{2}{|c|}{ Hipertensi } & \multicolumn{2}{|c|}{ Normotensi } & & & & \\
\hline & $f$ & $\%$ & $f$ & $\%$ & $\mathbf{F}$ & $\%$ & & \\
\hline $\begin{array}{l}\text { Tidak } \\
\text { Normal }\end{array}$ & 21 & 67,7 & 10 & 32,3 & 31 & 100 & & 2,49 \\
\hline Normal & 59 & 45,7 & 70 & 54,3 & 129 & 100 & 0,10 & $1,09-5,71$ \\
\hline Jumlah & 80 & & 80 & & 160 & & & \\
\hline
\end{tabular}

\section{Kejadian Hipertensi}

Hubungan kadar LDL dengan kejadian hipertensi

Proporsi fresponden yang memiliki kadar LDL tidak normal lebih banyak yang mengalami hipertensi dari pada normotensi. Hasil uji statistic chi-square diperoleh nilai $p=0,01$. Dengan nilai $O R=1,8$ dan $95 \% \mathrm{Cl}(0,94-3,43)$. Dimana kadar LDL tidak normal merupakan faktor resiko terjadinya hipertensi sebesar 1,8 kali dari pada yang memiliki kadar LDL normal.

Tabel 4. Hubungan Kadar LDL dengan Kejadian Hipertensi

\begin{tabular}{|c|c|c|c|c|c|c|c|c|}
\hline \multirow{3}{*}{$\begin{array}{l}\text { Kadar } \\
\text { LDL }\end{array}$} & \multicolumn{4}{|c|}{ Kejadian Hipertensi } & \multirow{2}{*}{\multicolumn{2}{|c|}{ Jumlah }} & \multirow{3}{*}{$\mathbf{P}$} & \multirow{3}{*}{$\begin{array}{c}\text { OR } \\
(95 \% \mathrm{Cl})\end{array}$} \\
\hline & \multicolumn{2}{|c|}{ Hipertensi } & \multicolumn{2}{|c|}{ Normotensi } & & & & \\
\hline & $f$ & $\%$ & $f$ & $\%$ & $F$ & $\%$ & & \\
\hline $\begin{array}{l}\text { Tidak } \\
\text { Normal }\end{array}$ & 36 & 59 & 25 & 41 & 61 & 100 & & 1,8 \\
\hline Normal & 44 & 44,4 & 55 & 55,6 & 99 & 100 & 0,10 & $0,94-3,43$ \\
\hline Jumlah & 80 & & 80 & & 160 & & & \\
\hline
\end{tabular}

\section{PEMBAHASAN}

Hubungan kolesterol total dengan kejadian hipertensi

Dalam penelitian ini ditemukan melalui analisis independent sample t-test kadar kolesterol responden hipertensi lebih tinggi dari pada kadar kolesterol total responden normotensi dan nilai uji statistik chi-square menunjukkan terdapat hubungan yang bermakna antara kadar kolesterol total dengan kejadian hipertensi. Dan berdasarkan nilai OR, ditemukan kadar kolesterol total tidak normal merupakan faktor resiko terjadinya hipertensi sebesar 2,09 kali dari kolesterol normal.

Hal ini sesuai dengan teori terjadinya aterosklerosis. Dimana Hiperkolesterolemia menjadi faktor resiko terjadinya hipertensi yang diawali dengan proses aterosklerosis pada pembuluh darah akibat terbentuknya gel busa. Kemudian membentuk bercak perlemakan yang akan menyebabkan terjadinya disrubsi endothelium. Akhirnya faktor pertumbuhan akan menyebabkan gel menjadi aterosklerosis lanjut. ${ }^{14}$ Hasil penelitian ini diperkuat oleh hasil penelitian yang dilakukan oleh Maulana dimana terdapat hubungan yang signifikan antara kadar kolesterol total terhadap kejadian hipertensi yang dilakukan di wilayah Banjar dengan nilai $\mathrm{p}=0,02$. Hipertensi tingkat I, kadar kolesterol yang mendominasi adalah kolesterol normal, hipertensi tingkat II dan III yang mendominasi adalah kolesterol agak tinggi dan tinggi. Tetapi terdapat juga perbedaan dengan penelitian yang dilakukan oleh Supryono 2008, dimana kadar kolesterol total pada usia $\leq 45$ tahun tidak menunjukkan hubungan yang signifikan terhadap gangguan cardiovascular, dengan nilai $\mathrm{p}=0,08$. Sementara menurut Lilianti, ketebalan tunica intima lebih dipengaruhi oleh kadar HDL dan LDL. ${ }^{16}$

\section{Hubungan HDL dengan kejadian hipertensi}

Berdasarkan uji analisis independent sample t-test menunjukkan terdapat perbedaan antara kadar HDL responden hipertensi dengan responden normotensi. Hasil uji statistik chi-square menunjukkan tidak terdapat hubungan yang bermakna antara kadar HDL dengan kejadian hipertensi dan kadar HDL bukan faktor risiko terjadinya hipertensi. Meskipun rerata kadar HDL penderita hipertensi cenderung normal tetapi jika dilihat proposri responden banyak pada usia > 55 tahun dan jenis kelamin perempuan. Dimana pada usia tersebut, perempuan mengalami perubahan hormonal terutama esterogen yang mempengaruhi kadar HDL. Selain itu, perempuan juga memiliki sensitivitas terjadinya hipertensi akibat asupan garam .Asupan garam yang tinggi tersebut terdapat dalam pola makanan masyarakat Kota Padang. Peningkatan jumlah garam di ekstrasel akan merangsang pusat rasa haus di otak menyebabkan keinginan untuk minum meningkat hingga kadar normal. Selai itu terjadi perangsangan ADH yang memicu ginjal untuk menyerap air dalam jumlah besar di tubulus ginjal hingga volume urin akan menurun. ${ }^{14,17-19}$

Hasil penelitian ini juga sama dengan temuan Japensen yang menyatakan bahwa HDL tidak memiliki hubungan yang bermakna dengan peningkatan 
tekanan darah sistolik pada pria. Tetapi hasil berbeda diungkapkan oleh Chen, dimana kadar HDL yang rendah mempengaruhi kejadian hipertensi, dimana kelompok responden normotensi memiliki kadar HDL $49 \pm 4 \mathrm{mg} / \mathrm{dl}$, dan hipertensi $37 \pm 2 \mathrm{mg} / \mathrm{dl}$ (21). Hasil ini juga tidak dapat membuktikan temuan Haryanto jika kadar HDL mempengaruhi ketebalan tunica intima yang menjadi salah satu faktor hipertensi. ${ }^{20-22}$

\section{Hubungan LDL dengan kejadian Hipertensi}

Berdasarkan hasil uji independen sampel $t$ test,tidak terdapat perbedaan yang bermakna antara kadar LDL orang hipertensi dengan normotensi. Hasil uji statistic chi-square juga menunjukkan tidak ada hubungan yang signifikan antara LDL dengan kejadian hipertensi, tetapi kadar LDL merupakan faktor resiko terjadinya hipertensi sebesar 1,8 kali pada kadar LDL tidak normal.

Hasil ini sama dengan penelitian yang dilakukan oleh Dirk, dimana tidak terdapat hubungan yang bermakna antara kadar LDL dengan peningkatan tekanan darah sistolik atau diastolik. Tetapi hasil ini sama dengan hasil penelitian yang dilakukan oleh Haryanto, dimana LDL mempengaruhi ketebalan tunica intima, arteri carotis pada murid di SMA Labschool Jakarta. Hal ini diketahui dengan melakukan USG pada arteri carotis. Sementara Supriyono menyatakan tidak adanya hubungan signifikan antara kadar LDL dengan gangguan kardiovaskular, dengan nilai $p=0,03$ dan OR 1,1 . $^{23,24}$

Jika di hubungkan dengan pola konsumsi masyarakat Minangkabau, meskipun makanan yang di konsumsi kaya dengan lemak jenuh yang berasal dari hewan, tetapi bumbu masakan yang di konsumsi sehari-hari memiliki kandungan anti oksidan yang sangat tinggi. Seperti kunyit, jahe lengkuas, daun jeruk, cabe merah, bawang merah, bawang putih, dan beberapa bumbu yang lebih jarang di pakai seperti kulit manis, merica, buah pala. Merupakan sumber vitamin $\mathrm{C}, \mathrm{A}, \mathrm{E}$ serta flavonoid .Zat-zat tersebut terutama flavonoid bersifat atheroprotektif melalui mekanisme peningkatan kemampuan platelet untuk melepaskan NO dan menghambat terbentuknya trombus. Peningkatan NO ini akan menyebabkan vasodilatasi pembuluh darah yang akan menurunkan tekanan darah. ${ }^{25}$

\section{Hubungan Trigliserida dengan Kejadian Hipertensi}

Hasil uji independent sample t-test menunjukkan terdapat perbedaan yang bermakna antara kadar trigliserida orang hipertensi dengan normotensi. Hasil uji statistik chi-square juga menunjukkan hubungan yang bermakna antara kadar trigliserida dan kejadian hipertensi. Dan trigliserida merupakan faktor resiko terjadinya hipertensi sebesar 2,49 kali.

Hasil ini sejalan dengan penelitian yang dilakukan oleh Darmastono, yang melakukan uji analisis bivariat menyatakan terdapat hubungan yang bermana antara kadar trigliserid dengan kejadian hipertensi baik sistolik maupun diastolik pada pegawai SMAN 8 Semarang. Persamaan juga terlihat dari hasil yang didapatkan oleh Ruben, dimana kadar kolesterol non HDL mempengaruhi kejadian hipertensi. Terlihat dari hubungan yang bermakna antara kadar kolesterol non HDL dengan tekanan darah sistolik yang lebih tinggi (>120 $\mathrm{mmHg}$ ) dengan nilai $p=0,03$, dan tekanan darah diastolik 0,035 . Tetapi perbedaan hasil di dapatkan dari penelitian Haryanto, dimana tidak ada hubungan ketebalan tunica intima dengan kadar trigliserida. ${ }^{22,26,27}$

Pada responden penelitian, sebelum dilakukan pengambilan darah di haruskan berpuasa selama 10-12 jam.Dalam keadaan berpuasa lipoprotein berdensitas rendah (VLDL) banyak mengandung trigliserida. Terutama jika responden menderita obesitas akan meningkatkan resiko hipertrigliseridemia. $^{28}$

Hal ini berbeda pemeriksaan yang dilakukan pada saat setelah berpuasa yang di dapatkan oleh Mughni 2007, dimana puasa dapat menurunkan kadar trigliserida darah. Tetapi pemeriksaan yang dilakukan adalah setelah berpuasa selama 29 hari yang di bandingkan dengan responden yang tidak berpuasa selama 29 hari. Sehingga terdapat perbedaan waktu dan durasi puasa pada kedua sampel. ${ }^{29}$

\section{KESIMPULAN}

Berdasarkan penelitian ini kejadian sebagian profil lipid yaitu kolesterol total dan trigliserida memiliki hubungan yang bermakna dengan kejadian hipertensi pada masyarakat Etnik Minangkabau, terutama yang berada di Kota Padang. Sementara kadar HDL dan LDL tidak memiliki hubungan yang bermakna dengan kejadian hipertensi pada masyarakat yang sama.

\section{DAFTAR PUSTAKA}

1. Kartikawati A. Prevalensi dan determinasi hipertensi pada pasien puskesmas di Jakarta Utara (skripsi). Universitas Indonesia; 2007.

2. Andra. Konas InaSh I. Simposia. 2007; 6(7). Tersedia dari: URL: HYPERLINK http://www.majalah-farmacia.

3. Yogiantoro M. Hipertensi esensial. Dalam: Sudoyo A, Setyohadi B, Alwi I, Simadibrata M, Setiati S, editor. Buku Ajar Ilmu Penyakit Dalam Jilid I. Jakarta: Pusat Penerbitan Departemen IImu Penyakit Dalam Fakultas Kedokteran Universitas Indonesia; 2007. hlm.610-14.

4. Panggabean MM. Penyakit jantung hipertensi. Dalam: Aru W. Sudoyo, editor. Buku Ajar IImu Penyakit Dalam Jilid III. Edisi ke-4. Jakarta: Pusat Penerbitan Departemen IImu Penyakit Dalam Fakultas Kedokteran Universitas Indonesia; 2006.

5. Zulkifli SA. Hubungan derajat hipertensi dengan kolesterol pada pasien hipertensi RSUP Adam Malik Medan Tahun 2010 (skripsi). Medan: Universitas Sumatera Utara; 2011.

6. Rahajeng E, Sulistyowati T. Prevalensi hipertensi dan determinannya di Indonesia. Pusat Penelitian Biomedis dan Farmasi Badan Penelitian Kesehatan, Departemen Kesehatan RI. Majalah Kedokteran Indonesia. 2009; 59(12).

7. Hidayah R. Faktor Resiko hipertensi pada pasien rawat jalan pada poliklinik khusus ginjal hipertensi bagian penyakit dalam RSUP. M. Djamil Padang (skripsi). Padang: Universitas Andalas; 2001.

8. Lydia HA. Studi prevalensi dan determinasi prevalensi hipertensi di provinsi kepulauan Bangka Belitung (skripsi). Jakarta: Universitas Indonesia; 2007.

9. Waspadji S. Asupan zat gizi dan beberapa zat gizi pada penderita hiperlipidemia dalam 
pengkajian status gizi studi epidemiologi. Jakarta: Balai Penerbit Fakultas Kedokteran Universitas Indonesia; 2003.

10. Sargowo D. Peranan kadar trigliserida dan lipoporotein sebagai faktor resiko penyakit jantung koroner (studi pendahuluan). Malang: Fakultas Kedokteran Universitas Brawijaya; 2002.

11. Depkes. Pedoman surveilans penyakit jantung dan pembuluh darah. Jakarta: Depkes RI; 2007.

12. Sulastri D, Rahmatini, Liputo NI, Edward Z. Pengaruh asupan antioksidan terhadap ekspresi gen eNOS3 pada penderita hipertensi etnik Minangkabau. Majalah Kedokteran Indonesia. 2010; 60(12).

13. Kamso S, Purwantyastuti, Ratna J. Dislipidemia pada usia lanjut di kota Padang. Makara of Health Series. 2002;6(2).

14. Arthur CG, John EH. Metabolisme lipid. Dalam: Luqman YA, Huriawati $\mathrm{H}$, Andita $\mathrm{N}$, Nanda W. Ed. Indonesia. Buku Ajar Fisiolog Kedokteran. Edisi ke-11. Jakarta: EGC; 2008. hlm.882-94.

15. Maulana I. Hubungan kadar kolesterol total dengan hipertensi pada lansia di wilayah kerja puskesmas Sungai Besar Banjar Baru. Al-Ulum. 2008; 36(2):11-5.

16. Lilijanti $S$, et al. Ketebalan tunica intimamedia arteri carotis dan fungsi ventrikel serta profil lipid pada anak dengan sindrom nefrotik relaps frekuen dependen steroid. Sari Pediatri. 2007; 9(4).

17. Rachman F. Berbagai faktor yang berhubungan dengan kejadiah hipertensi pada lansia (studi kasus di RS dr. Karyadi Semarang). Laporan Hasil Akhir Karya Tulis IImiah; 2011.

18. Lailani M. Gambaran tekanan darah tikus wistar jantan dan betina setelah pemberian diet tinggi garam (skripsi). Padang: Universitas Andalas; 2012.

19. Oswari LD. Kebiasaan makan dan penyakit modern. Dalam: Suharjo JB, editor. Buku Gaya Hidup dan Penyakit Modern. Edisi ke-1. Jogjakarta: Kanisius; 2008.
20. Jorgen Jeppensen, et al. High tryglicerides and low HDL cholesterol and blood pressure and risk of ischemic heart disease. American Heart Association. Hypertension. 2000; (36): 226-32.

21. Chen I, et al. High density lipoprotein turnover in patients with hypertension. American Heart Association. Hypertension. 1991;(17):386-93.

22. Haryanto $D$, Bambang $M$, Damayanti RS, Sudigdo S. Hubungan ketebalan tunica intima media arteri carotis media dengan obesitas pada remaja. Sari Pediatri. 2009; 11(3).

23. Dirk CF, et al. Low-density lipoprotein subfraction and cardiovascular risk in hypertension (Relationship to endothelial dysfunction and effects of treatment). American Heart Association. Hypertension. 2003; (41): 528-33.

24. Supriyono M. Faktor-faktor resiko yang berpengaruh terhadap kejadian penyakit jantung koroner pada kelompok usia 45 tahun (tesis). Semarang: Universitas Diponegoro; 2008.

25. Liputo NI, et al. Pemberian diet tinggi sumber antioksidan dapat menurunkan kadar tekanan darah. Repositori Universitas Andalas; 2008.

26. Darmastono $P$. Hubungan antara persentasi lemak tubuh,lingkar pinggang, kolesterol total dalam darah dan trigliserida dengan tekanan darah (studi pada pegawai negeri sipil SMA 8 Semarang). Semarang: Program Studi IImu Gizi Fakultas Kedokteran Universitas Diponegoro; 2009.

27. Ruben $\mathrm{OH}$, et al. Dyslipidemia and the risk of incident hypertension in men. American Heart Association. Hypertension. 2006;(47): 45-50.

28. Jerold MO. Obesitas dalam prinsip-prinsip Ilmu penyakit dalam. Dalam Ahmad, H.A (ed. Kurt, J.I. et al.) Horrison. Edisi ke-13. Jakarta: EGC; 1999. hlm. 479-504

29. Mughni A. Pengaruh puasa ramadhan terhadap faktor-faktor risiko aterosklerosis studi pada profil lipid, gula darah, tekanan darah dan berat badan (tesis). Semarang: Pasca Sarjana Universitas Diponegoro; 2007. 